\title{
Sistim Pengawasan dan Pengendalian Linen sebagai Strategi Mengurangi Angka Linen Hilang
}

\section{Linen Monitoring and Controlling System as Decreasing Linen Lost Strategy}

\author{
Nikma Fitriasari ${ }^{1}$, Tuti Hariyanto ${ }^{1}$, Navis Yuliansyah $^{2}$ \\ ${ }^{1}$ Program Studi Magister Manajemen Rumah Sakit Fakultas Kedokteran Universitas Brawijaya Malang \\ ${ }^{2}$ Rumah Sakit Islam Gondanglegi Malang
}

\begin{abstract}
ABSTRAK
Hasil studi pendahuluan di Rumah Sakit Islam Gondanglegi ditemukan bahwa masih ada kejadian linen hilang sebanyak $3,4 \%$ yang menunjukkan pentingnya pengembangan sistem pengawasan dan pengendalian (wasdal) linen. Kajian dilakukan untuk mengembangkan sistem wasdal linen dan mengevaluasi implementasinya. Pengembangan sistem dilakukan melalui workshop yang didahului dengan kajian pustaka dan mengikuti pelatihan. Sistem wasdal disusun dalam bentuk alur sistem dan dokumen, yang kemudian disosialisasikan dan diuji coba dalam jangka waktu dua minggu. Hasil penelitian menunjukkan adanya penurunan linen hilang sebesar 2,6\% sebelum dan sesudah implementasi sistim wasdal linen hilang. Sistim wasdal yang diterapkan terdiri dari lima standar prosedur operasional dan delapan dokumen pendukung.
\end{abstract}

Kata Kunci: Linen hilang, rumah sakit, sistim pengawasan dan pengendalian

\begin{abstract}
Results of preliminary studies at Islamic Hospital Gondanglegi strengthen the need of linen monitoring and control system development since there were incidences of linen lost as much as 3.4\%. This study was conducted to develop a linen monitoring and control system, and evaluate its implementation. System development was done through training and workshops preceded by literature study. The monitoring and control system were arranged in the forms of flow chart and document, which were then disseminated and tested within two weeks. The results show a decrease of 2,6\% linen missing before and after implementation of the system. The monitoring and control system applied consists of five standard operational procedures and eight supporting documents.
\end{abstract}

Keywords: Hospital, lost linen, monitoring and control system,

Korespondensi: Nikma Fitriasari. Program Studi Magister Manajemen Rumah Sakit Fakultas Kedokteran Universitas Brawijaya Malang, Jl. Veteran Malang Jawa Timur Tel. (0341) 568989Email:nikma.fitriasari@gmail.com 


\section{PENDAHULUAN}

Pelayanan laundry merupakan salah satu unit penunjang non medik yang mempunyai peran penting namun sering diabaikan. Keberhasilan pelayanan medik dapat dicapai bila didukung oleh pelayanan penunjang medik dan non medik (1). Pelayanan laundry masih dianggap unit yang kurang penting, non produktif dan unit pemborosan oleh sebagian besar rumah sakit. Pelayanan laundry sebenarnya mempunyai peran penting diantaranya melakukan pengelolaan linen rumah sakit, khususnya linen kelengkapan tempat tidur pasien rawat inap dan kamar operasi. Penanganan linen yang baik diperlukan untuk mencegah terjadinya infeksi silang dan infeksi nosokomial bagi pasien sehingga dapat memberikan kepuasan dan kenyamanan bagi pasien (2).

Salah satu fungsi manajemen linen adalah pengawasan atau pengendalian (wasdal). Pengawasan adalah suatu kegiatan untuk memperoleh apakah pelakanaan kegiatan telah dilakukan sesuai dengan rencana semula. Pengendalian adalah proses pemantauan, penilaian dan pelaporan rencana atas pencapaian tujuan yang telah ditetapkan untuk tindakan korektif guna penyempurnaan lebih lanjut. Pengawasan dan pengendalian linen berupa terdiri dari: 1) pembuatan inventarisasi linen secara periodik atas linen yang sedang berputar maupun linen yang ada di dalam stok, 2) pencatatan pengiriman dan penerimaan linen. Pengawasan dan pengendalian ini dilakukan di ruang linen dan di bagian laundry $(3,4)$. Wasdal di ruang linen berupa penerimaan linen bersih, pengiriman linen kotor dan pencatatan jumlah serta keadaan fisik linen. Wasdal di ruang laundry berupa penerimaan linen kotor, pencucian dan pengiriman linen bersih. Pelaksanaan wasdal linen memerlukan sistem berupa prosedur dan dokumen untuk mencatat semua transaksi sehingga peredaran linen dapat diawasi dan keamanannya terjamin. Ruang lingkup wasdal linen dimulai dari persediaan kebutuhan linen, pengadaan linen, penyimpanan linen, penggunaan linen dan distribusi linen (4).

Salah satu indikator mutu dalam manajemen linen sesuai dengan Standar Pelayanan Minimal Rumah Sakit tahun 2008 adalah tidak adanya kejadian linen yang hilang. Indikator ini menunjukkan efisiensi dan efektifitas pengendalian mutu pelayanan laundry (5). Hasil studi pendahuluan di Rumah Sakit Islam (RSI) Gondanglegi ditemukan bahwa pencapaian SPM tahun 2014 hanya mencapai nilai rerata 49,9\% dari 20 indikator yang ada. Pencapaian yang rendah di Pelayanan Laundry disebabkan karena masih ada kejadian linen hilang sebanyak $3,4 \%$. Linen yang sering hilang adalah baju pasien $(1,1 \%)$, selimut tebal $(0,8 \%)$, dan steek laken $(0,67 \%)$. Kehilangan linen tebanyak terjadi di Unit Pelayanan Khusus Stroke/UPKS (36,6\%), Intensive Care Unit/ICU (24,4\%), dan Ruang Melati (9,6\%).

Tingginya angka kehilangan linen menunjukkan masih lemahnya fungsi wasdal dalam manajemen linen. Lemahnya sistem wasdal linen juga diidentifikasi dari studi pendahuluan yang melibatkan delapan kepala ruang melalui kuesioner dengan pendekatan fishbone dan diskusi untuk mengidentifikasi akar masalah dan alternatif solusi. Pengembangan sistem wasdal linen merupakan solusi yang dipilih. Kajian ini dilakukan untuk memaparkan proses pengembangan sistem wasdal linen dan dampak implementasinya dengan indikator jumlah linen hilang.

\section{METODE}

Berdasarkan hasil tapisan Mc Namara, solusi yang dipilih dalam menyelesaikan masalah linen hilang adalah pembuatan prosedur dan dokumen wasdal linen hilang dengan membuat Buku Panduan Sistim Wasdal Linen Hilang Rumah Sakit Islam Gondanglegi. Penyusunan buku tersebut dilaksanakan pada tanggal 20-28 September 2015 dengan cara mencari daftar pustaka, mengikuti workshop Manajemen Linen, dan berdiskusi dengan Tim Manajemen. Buku Panduan Sistim Wasdal Linen Hilang disahkan oleh Direktur Rumah Sakit Islam Gondanglegi pada tanggal 1 Oktober 2015. Buku tersebut disosialisasikan pada tanggal 3 Oktober 2015 yang dihadiri oleh kepada Kepala Bidang Keperawatan, Wakil Bidang Keperawatan, Kepala Ruang Dahlia, Kepala Ruang Anggrek, Kepala Ruang Mawar, Kepala Ruang Melati, Kepala Ruang Teratai, Kepala Ruang ICU, Kepala Ruang UPKS, Kepala Ruang Cempaka, Kepala Linen, dan petugas linen. Setelah dilakukan sosialisasi, sistim wasdal linen hilang diimplementasikan dalam uji coba 2 minggu, yaitu pada tanggal 7-18 Oktober 2015.

\section{HASIL}

Buku Panduan Sistim Wasdal Linen Hilang memuat alur pelayanan linen sebagai panduan dalam implementasi sistim wasdal. Alur pelayanan linen disajikan pada Gambar 1.

Ada perbedaan alur pelayanan linen dalam Sistim Wasdal Linen dibandingkan dengan alur pelayan linen sebelumnya. Perbedaan tersebut diantaranya: 1) alur pelayanan linen meliputi alur pelayanan ketersediaan kebutuhan, pengadaan, penyimpanan, penggunaan, dan distribusi linen; 2) alur pelayanan linen dilengkapi dengan 8 dokumen penunjang, diantaranya Kartu Inventaris Linen, Kartu Stok Linen, Checklist Linen, Checklist Linen Keluar, Checklist Linen Kotor, Formulir Disribusi Linen, Formulir Penggantian Linen, dan Laporan Bulanan Linen. Disamping itu dalam sistem wasdal baru dikembangkan mekanisme pencocokkan jumlah linen saat pengambilan linen kotor dan pengembalian linen bersih antara petugas Unit Linen Laundry dan Unit Rawat Inap dengan melakukan otorisasi di Formulir Distribusi Linen serta mekanisme penggantian linen hilang melalui pembuatan kronologis kejadian.

Alur dokumen dalam Sistim Wasdal Linen pada Gambar 2 dikelompokkan menjadi dokumen bulanan, dokumen harian, dan dokumen periodik. Dokumen bulanan adalah dokumen yang dibuat setiap bulan dan triwulan. Dokumen bulanan terdiri dari laporan bulanan linen dan kartu inventaris linen. Laporan bulanan linen dibuat rutin setiap bulan untuk mengetahui penambahan linen, linen yang rusak, linen yang dibebankan kepada pasien, dan linen hilang sehingga diketahui jumlah linen di akhir bulan. Kartu inventaris linen dibuat untuk mengetahui jumlah linen di ruangan yang diperbarui setiap tiga bulan sekali berdasarkan hasil laporan bulanan linen.

Dokumen harian adalah dokumen yang harus dibuat setiap hari untuk mengetahui posisi linen dalam satu hari. Dokumen harian terdiri dari kartu stok linen, checklist linen, checklist linen kotor, dan formulir distribusi linen. Kartu stok linen dibuat untuk mengetahui jumlah linen yang ada di lemari penyimpanan linen. Kartu ini diisi setiap mengambil linen dari lemari dan memasukkan linen bersih dari petugas linen.

Checklist linen dibuat untuk mengetahui jumlah linen yang 


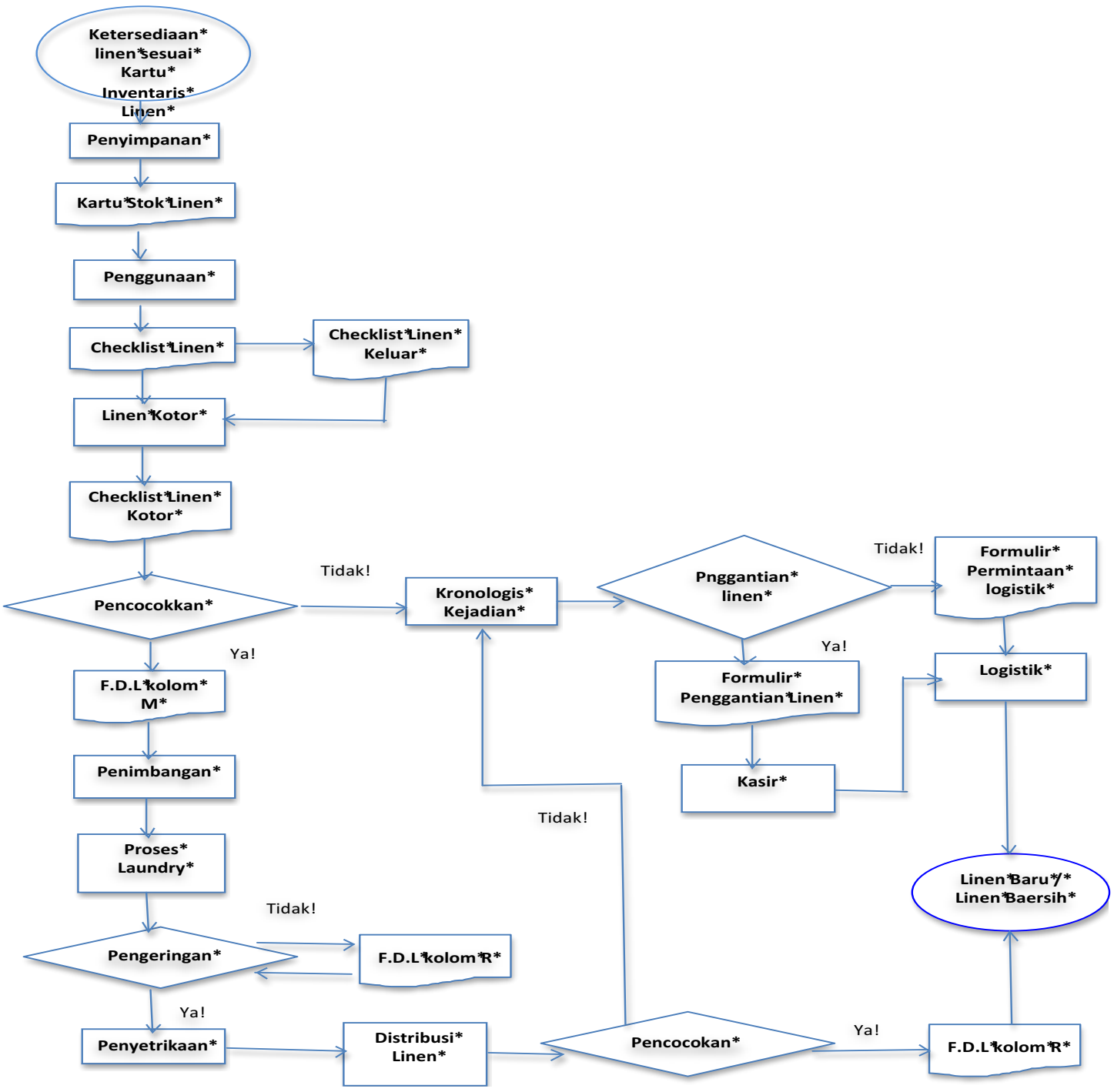

Gambar 1. Alur pelayanan linen dalam buku panduan sistim $\mathbf{w}$ asdal linen $\mathbf{h}$ ilang Keterangan: Formulir Distribusi Linen (FDL)

terpakai oleh pasien. Checklist ini diletakkan di bed pasien atau di dalam rekam medis. Checklist linen kotor dibuat untuk mengetahui jumlah linen yang ada di bak kotor. Checklist ini diletakkan di dekat bak kotor. Pengisian jumlah linen dibedakan antara linen infeksius dan non infeksius. Formulir distribusi linen dibuat untuk mengetahui jumlah linen yang ada di Unit Linen Laundry. Dokumen ini harus dibuat oleh petugas ruangan dan petugas Unit Linen Laundry.

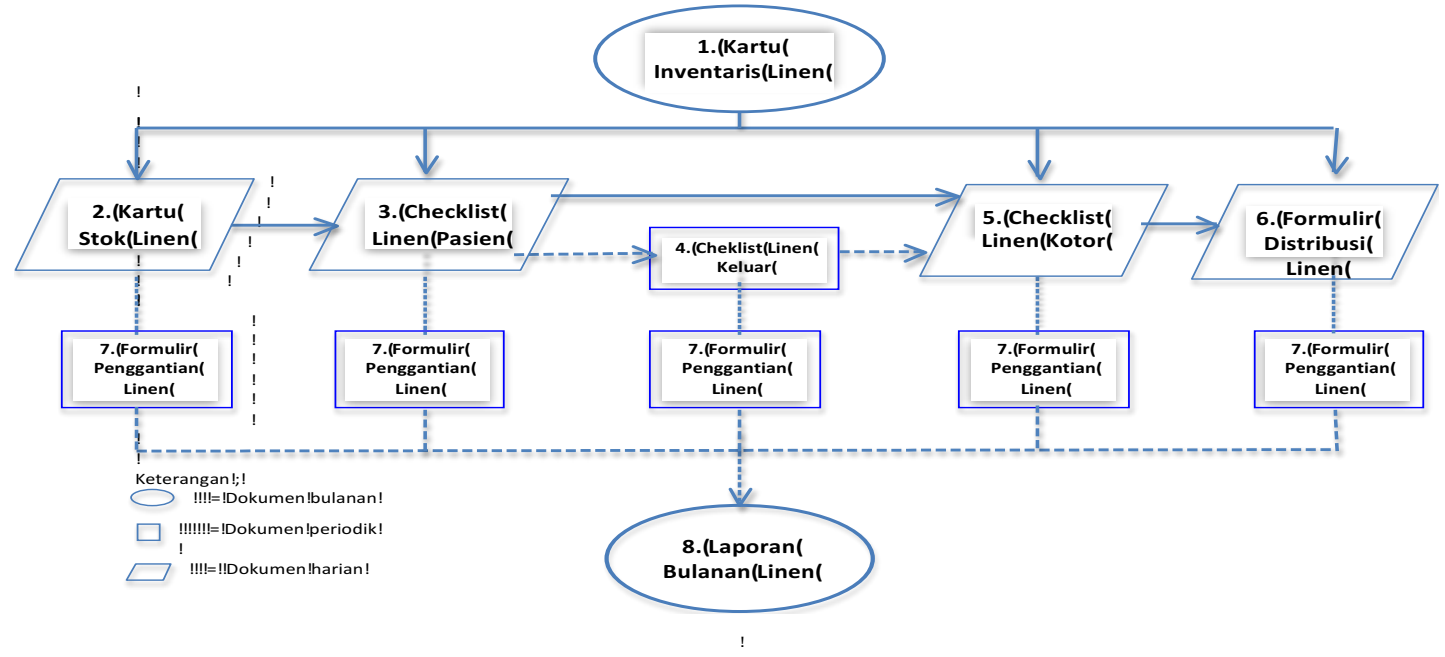

Gambar 2 . Alur dokumen sistim wasdal linen hilang 
Dokumen periodik adalah dokumen yang dibuat dalam waktu tertentu. Dokumen perioik terdiri dari checklist linen keluar dan formulir penggantian linen. Checklist linen keluar dibuat bila ada pasien keluar dari rumah sakit (sembuh, dirujuk, perlu pemeriksaan penunjang, atau meninggal) dengan membawa linen rumah sakit. Formulir penggantian linen dibuat bila hasil analisa kronologis kejadian linen hilang diputuskan ada penggantian terhadap linen yang hilang.

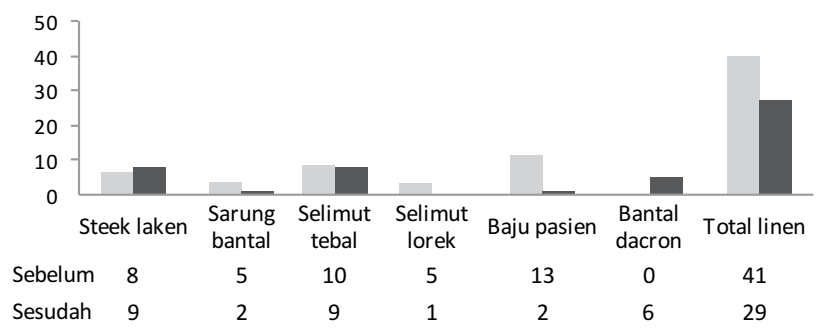

Gambar 4. Jenis linen hilang

Evaluasi hasil implementasi didapatkan penurunan jumlah linen yang hilang berdasarkan jenis linen (Gambar 3) dan distribusi tiap ruangan (Gambar 4). Penurunan linen hilang sebesar 2,6\% dibandingkan sebelum ada sistim wasdal linen hilang. Jenis linen hilang yang terbanyak sebelum implementasi adalah selimut tebal, baju pasien, dan steek laken, sedangkan linen hilang setelah implementasi adalah selimut tebal, steek laken dan bantal dacron. Selimut tebal masih menjadi jenis linen yang paling banyak hilang sebelum dan sesudah implementasi.

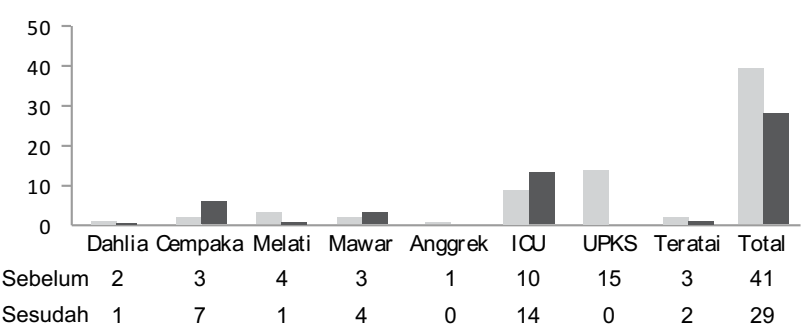

Gambar 5. Distribusi linen hilang

Gambaran distribusi linen hilang yang terbanyak sebelum implementasi adalah ruang UPKS, ICU, dan Melati, sedangkan linen hilang sesudah implementasi adalah ruang ICU, ruang Cempaka, dan ruang Mawar. Ruang ICU tetap menjadi ruangan dengan linen hilang terbanyak sebelum dan sesudah implementasi. Kendala yang ditemui dalam implementasi adalah keterlambatan pengadaan dokumen sistim wasdal di ruangan, belum semua dokumen sistim wasdal diisi lengkap di ruangan, dan belum semua petugas melakukan otorisasi di dokumen sistim wasdal.

\section{DISKUSI}

Penerapan Sistem Pengawasan dan Pengendalian Linen diawali dengan membuat SPO (Standar Prosedur Operasional) dan dokumen yang dipadukan dalam Buku
Pedoman Pengawasan dan Pengendalian Linen Hilang. Salah satu faktor yang mempengaruhi kinerja pengelolaan linen rumah sakit adalah pedoman yang jelas berupa prosedur pelaksanaan (2). Penyusunan SPO untuk memberikan kejelasan tugas dan wewenang bagi petugas yang berkaitan dengan penggunaan linen. Pendokumentasian sistem dalam berbagai bentuk form pencatatan dimaksudkan untuk mengetahui secara pasti keberadan linen dari waktu ke waktu. Sistim Wasdal tidak terlepas dari aktivitas pencatatan terhadap setiap transaksi. Kegiatan pencatatan tidak hanya untuk mengetahui linen secara kuantitatif, tetapi mengetahui kondisi fisik linen dan biaya yang menjadi beban di pelayanan laundry (3).

Standar prosedur operasional yang dibuat dalam sistim wasdal linen terdiri dari sistim pemenuhan kebutuhan, sistim pengadaan, sistim penyimpanan, sistim penggunaan dan sistim distribusi sesuai dengan managemen logistik (6). Sistim pemenuhan kebutuhan linen di rumah sakit belum sesuai dengan standar ketersediaan linen yaitu 1 : 5 par. Hasil evaluasi sistem didapatkan masih banyak ruangan yang belum memenuhi standar jumlah linen, ada yang terlalu banyak dan ada yang terlalu sedikit. Hal ini disebabkan karena sistim yang digunakan oleh RSI Gondanglegi dalam menghitung kebutuhan linen ruangan berdasarkan nilai BOR ruangan.

Pada sistem pengadaan, linen hilang dan linen rusak di ruangan tidak langsung dilakukan penggantian linen sehingga jumlah inventaris linen di ruangan terus berkurang. Pengadaan linen baru dilakukan melalui pengajuan Rencana Kerja Anggaran (RKA) di akhir tahun untuk tahun berikutnya. Pengajuan RKA untuk pengadaan linen di rumah sakit tidak ada perencanaan tetapi hanya berdasarkan kebutuhan saat itu. Jumlah linen yang tidak sesuai standar menyebabkan frekuensi penggunaan linen meningkat sehingga kejadian linen rusak juga semakin meningkat.

Sistim penyimpanan linen di tiap ruangan yang standar adalah linen disimpan di lemari yang bersih dan ada pencatatan. Tempat penyimpanan linen di tiap rungan sudah sesuai standar namun belum ada pencatan masuk keluarnya linen dari lemari penyimpanan. Adanya tempat penyimpanan linen yang memadai diperlukan demi kemanan linen ditunjang dengan sistim pencatatan yang akurat terhadap linen.

Standar sistem penggunaan linen menganut prinsip FIFO (First In First Out). Penelitian Machfud dan Pinatik tahun 2014 menyatakan bahwa barang yang pertama kali datang harus terlebih dahulu dikeluarkan untuk mencegah terjadinya kadaluarsa atau kerusakan. Prinsip FIFO belum diterapkan di rumah sakit. Hasil observasi didapatkan bahwa petugas meletakkan linen bersih di susunan paling atas, dan saat memerlukan linen baru, petugas juga mengambil linen dari susunan paling atas. Proses ini menyebabkan frekuensi penggunaan linen meningkat pada jenis linen tertentu sehingga menyebabkan tingkat kerusakan linen juga meningkat (7).

Sistim distribusi linen di rumah sakit sudah menggunakan pencatatan dan pelaporan. Pencatatan dilakukan di buku pencatatan linen yang diambil dari ruangan dan dikembalikan dari Unit Linen Laundry. Model buku pencatatannya belum seragam di semua ruangan dan hanya beberapa ruangan yang menjalankan pencatatan. Selain itu, ada kejadian beberapa linen tertukar dengan 
ruangan lain. Hal ini disebabkan karena sistem pencatatan yang masih lemah dan identitas linen yang belum standar. Identitas linen tiap ruangan hanya dibedakan dengan kain warna yang dijahit di ujung linen. Penelitian Ingniati tahun 2004 menyatakan bahwa linen yang didistribusi harus diberi nama rumah sakit dan tanggal mulai pemakaian untuk memudahkan pengontrolan. Sistem inventarisasi yang baik dapat mengukur tingkat kerusakan, kehilangan selama pemakaian dibnadingkan dengan penerimaan barang sehingga dapat diketahui tingkat efiisiensi. Bila sitem inventarisasi dikerjakan selama 3-5 tahun, data tersebut dapat digunakaan untuk evaluasi tingkat kebutuhan, kehilangan dan kerusakan (3).

Hasil penelitian menunjukkan bahwa selimut tebal menjadi salah satu linen yang sering hilang sebelum dan sesudah implementasi. Hal ini disebabkan karena selimut tebal termasuk jenis linen yang bagus dan mahal, sehingga pasien ingin memiliki. Upaya antisipasi rumah sakit adalah melakukan komunikasi di awal pasien masuk bahwa semua benda yang ada di rumah sakit adalah milik rumah sakit. Bila pasien ingin memiliki, pasien dapat membeli dari pihak rumah sakit.

Pelaksanaan implementasi sistim wasdal linen hilang di RSI Gondanglegi menemui beberapa kendala diantaranya keterlambatan pengadaan dokumen sistim wasdal di ruangan, belum semua dokumen sistim wasdal diisi lengkap di ruangan, dan belum semua petugas melakukan otorisasi di dokumen sistim wasdal. Semua kendala dalam teknis implementasi sistim wasdal linen hilang disebabkan karena rumah sakit belum memiliki struktur organisasi di Unit Linen Laundry. Belum terbentuknya struktur organisasi menyebabkan belum terbentuknya fungsi manajemen yang berhubungan dengan pelaporan serta belum ada penugasan dan tanggung jawab delegasi kekuasaan. Penelitian Fitranty menyatakan bahwa struktur organisasi menkontribusi pada lingkungan pengendalian yang baik. Hal ini karena adanya kerangka yang menyeluruh untuk perencanaan, koordinasi dan pengendalian operasi (8). Menurut Oktariana, struktur organisasi diartikan sebagai cara dimana kegiatan orang dikoordinasikan untuk mencapai suatu tujuan. Struktur organisasi yang diimplementasikan secara wajar dan tepat dapat membentuk suatu organisasi yang lebih efektif (9). Dalam fungsi manajemen dalam pengarahan, seorang manajer dalam struktur organisasi mengarahkan orangorang yang ada dalam organisasi sesuai peranan masing-

\section{DAFTAR PUSTAKA}

1. Suardi. Peran pimpinan Rumah Sakit dalam Meningkatkan Kinerja Pegawai di Rumah Sakit Aji Batara Agung Samboja Kabupaten Kutai Kartanegara. eJournal Ilmu Pemerintahan. 2014; 2(3): 2210-2223.

2. Nugraheni E dan Mulasari SA. Analisis Tingkat Kepatuhan Petugas Linen Laundry terhadap SOP Pencucian Linen Laundry di Rumah Sakit $X$ di Yogyakarta Tahun 2013. Medika Respati. 2014; 9(2): 16.

3. Porwani S. Peran Komunikasi dalam Fungsi Manajemen pada PT. Astra International-Honda TBK Plaju Palembang. Orasi Bisnis. 2014;12(2): 9.

4. Departemen Kesehatan Republik Indonesia. Pedoman Manajemen Linen di Rumah Sakit. Jakarta: masing sehingga tujuan organisasi dan bagian-bagiannya tercapai (10). Penelitian Furterer menyatakan bahwa upaya untuk menurunkan angka kehilangan linen adalah membuat kebijakan dan prosedur termasuk memberi delegasi staf untuk mengontrol linen di ruangan. Tugas dari staf adalah membuat pertemuan rutin tiap bulan dan mengembalikan linen yang rusak (11).

Penyebab lain dari kendala dalam pelaksanaan implementasi sistim wasdal linen hilang disebabkan karena waktu yang sempit dalam evaluasi implementasi sistim. Penelitian Roger menyatakan bahwa sebelum seseorang mengadopsi perilaku baru, terjadi beberap proses dalam dirinya berupa awareness (kesadaran), interest (tertarik), evaluation, trial (mencoba) dan adoption (berperilaku). Urutan proses tersebut memerlukan waktu sehingga seorang berperilaku sesuai dengan pengetahuan dan kesadaran (12).

Adapun langkah-langkah yang dilakukan untuk mengoptimalkan implementasi Sistim Wasdal Linen Hilang di RSI Gondanglegi adalah; 1). Persiapan, meliputi pembentukan Tim Manajemen Linen Rumah Sakit, mengkaji kebutuhan penggandaan dokumen, merancang program monitoring dan evaluasi implementasi sistim wasdal linen, dan menetapkan anggaran, 2). Pelaksanaan, meliputi melaksanakan monitoring implementasi sistim wasdal di setiap ruangan dengan melihat pengisian dokumen wasdal dan melakukan pertemuan rutin bulanan untuk mempresentasikan hasil monitoring, 3). Penilaian/evaluasi, meliputi evaluasi dalam bentuk pengamatan ulang terhadap kepatuhan pengisian dokumen sistim wasdal, melakukan penghitungan linen tiap triwulan untuk dapat membandingkan kejadian linen hilang sebelum dan sesudah intervensi.

Sistim Wasdal Linen Hilang memiliki 5 standar prosedur operasional yang terdiri dari SPO Pemenuhan Kebutuhan, SPO Pengadaan, SPO Penyimpanan, SPO Penggunaan dan SPO Distribusi. Dokumen dalam Sistim Wasdal Linen Hilang tediri dari 8 dokumen yaitu kartu inventaris linen, kartu stok linen, formulir distribusi linen, chekclist linen, checklist linen kotor, checklist linen keluar, formulir penggantian, dan laporan bulanan linen. Saran yang dapat diberikan adalah rumah sakit membuat pengorganisasian di Unit Linen Laundry dan sistim wasdal linen hilang dapat dijalankan secara konsisten. Perlu penelitian lebih lanjut untuk mengetahui efisiensi biaya implementasi sistim wasdal, membuat sistem pencegahan linen rusak dan pencegahan infeksi nosokomial.

Direktorat Jenderal Pelayanan Medik; 2004.

5. Syamsiah J, Wahyu T, dan Mansur M. Peningkatan Mutu Pelayanan RSI Unisma Malang melalui Reformasi Manajemen Laundry dan Linen. Jurnal Kedokteran Brawijaya. 2015; 28(2): 148-152.

6. Bowersox DJ, Closs DJ, and Cooper MB. Supply Chain Logistics Management. New York: McGraw-Hill; 2002.

7. Ali M dan Pinatik S. Peran Controller dalam Usaha Meminimalisasi Resiko Kehilangan Pesediaan Barang Dagangan pada Jumbo Swalayan Manado. Jurnal Riset Ekonomi, Manajemen, Bisnis dan Akuntansi. 2014; 2(2): 766-774.

8. Fitranty SA dan Baridwan Z. Studi Fenomenologi: Pemaknaan Sistem Pengendalian Internal- 
Lingkungan Pengendalian pada Dea Cake and Bakery. Jurnal IImiah Mahasiswa Fakultas Ekonomi Brawijaya. 2014; 2(1): 1-27.

9. Oktariansyah O. Evaluasi Struktur Organisasi terhadap Pengendalian Intern pada CV. Sedulur Palembang. Jurnal Media Wahana Ekonomika. 2015; 11(4): 28-36.

10. Gerdiman M dan Sutanto EM. A. Noor dan
Kesuksesan Dagadu. Agora. 2013; 1(1): 1-4.

11. Furterer SL. Applying Lean Six Sigma to Reduce Linen Loss in An Acute Care Hospital. International Journal of Engineering, Science and Technology. 2011; 3(7): 39-55.

12. Suriyanto RA. Pogram Pembangunan Kesehatan: Masyarakat Desa Wuwuharjo dalam Proyek Inovasi. Masyarakat Kebudayaan dan Politik. 2008; 21(2): 174-180. 